\title{
Survival and Growth of Mangrove Tree Seedlings in Different Types of Substrate on the Ajuruteua Peninsula on the Amazon Coast of Brazil
}

\author{
Rejane Silva Costa ${ }^{1}$, Erneida Coelho de Araujo ${ }^{1 *}$, Elaine Cristina Lopes de Aguiar ${ }^{1}$, \\ Marcus Emanuel Barroncas Fernandes' ${ }^{1}$, Rogerio Figueiredo Daher ${ }^{2}$ \\ ${ }^{1}$ Laboratório de Ecologia Manguezal, Universidade Federal do Pará, Bragança, PA, Brazil \\ ${ }^{2}$ Centro de Ciências e Tecnologias Agropecuárias, Universidade Estadual do Norte Fluminense, Campos dos \\ Goytacazes, RJ, Brazil \\ Email: rejane_bio07@yahoo.com.br, *erneida@ufpa.br, elaine_bio@yahoo.com.br, \\ mebf@ufpa.br, rogdaher@uenf.br
}

Received 31 May 2016; accepted 19 July 2016; published 22 July 2016

Copyright (C) 2016 by authors and OALib.

This work is licensed under the Creative Commons Attribution International License (CC BY). http://creativecommons.org/licenses/by/4.0/

(c) (i) Open Access

\section{Abstract}

The present study investigated the growth and survival of seedlings of Rhizophora, Avicennia, and Laguncularia raised in three different substrates: mangrove soil, latosol, and sand. The study was based on an entirely random factorial design $(3 \times 3) \times 3$, with three tree species, three substrates, and three replicates. The experiment was conducted in a nursery installed in the municipality of Bragança, in the northern Brazilian state of Pará. The seedlings were grown in $17 \mathrm{~cm} \times 27 \mathrm{~cm}$ polyethylene containers. Survival was calculated based on the percentage of germinated propagules surviving after 270 days. Seedling heights were evaluated using an analysis of variance (ANOVA) and morphological parameters were compared using Tukey's test. All three species were ready for replanting after 270 days. The $R$. mangle and $A$. germinans seedlings presented better rates of survival and growth on the substrates tested. All three species grew well in the substrates tested, and the production of seedlings in yellow latosol would appear to be the most effective approach.

\section{Keywords}

Replanting, Soil, Production of Seedlings, Mangrove, Brazilian Amazon

Subject Areas: Plant Science

\footnotetext{
${ }^{*}$ Corresponding author.

How to cite this paper: Costa, R.S., de Araujo, E.C., de Aguiar, E.C.L., Fernandes, M.E.B. and Daher, R.F. (2016) Survival and Growth of Mangrove Tree Seedlings in Different Types of Substrate on the Ajuruteua Peninsula on the Amazon Coast of Brazil. Open Access Library Journal, 3: e2777. http://dx.doi.org/10.4236/oalib.1102777
} 


\section{Introduction}

Worldwide, mangrove forests cover a total area of approximately 152,000 $\mathrm{km}^{2}$ [1], of which 8.5\% $\left(13,000 \mathrm{~km}^{2}\right)$ is found in Brazil, which is the country with the second largest area of this type of ecosystem. Approximately half of this area $\left(6516 \mathrm{~km}^{2}\right)$ is found on the Amazon coast, between the states of Pará and Maranhão [2]. In Pará, the mangroves form an almost continuous tract of forest lining the coast for $300 \mathrm{~km}$, with a total area of 2176.78 $\mathrm{km}^{2}$. The decline of these forests around the world is becoming increasingly evident, however, given the progressive growth of impacts such as the predatory extraction of the lumber produced by these systems [3].

A number of authors believe that unmanaged logging in mangrove forests may cause considerable alterations to the composition of these ecosystems or even their total elimination from some areas [4]-[7]. In Brazil, the exploitation of these systems has involved even more drastic impacts, such as the installation of shrimp farms at many locations in the northeast of the country [8], deforestation and lumbering in the southeast [9], and the construction of highways in the extreme north [10].

Despite these impacts, there have been a number of initiatives for the recuperation of mangrove forests in many areas around the Brazilian coast [11]. These efforts include the replanting of native species and the investigation of different techniques related to the recuperation of habitats, such as the care of the propagules, the production of seedlings, evaluation of the optimum period for planting propagules and transplanting seedlings, planting procedures and post-planting monitoring.

The development of adequate technologies for the production of the seedlings of native plants, including seed germination, seedling management, and the type of substrate used, is essential for the recuperation of degraded ecosystems [12]. Furthermore, the substrate used for the production of seedlings in degraded environments should present physical and chemical characteristics appropriate for the retention of both humidity and nutrients required by the plants [13]. In Brazil, only one study [11] has analyzed the relative value of different types of substrate for the production of mangrove tree seedlings, and this study was in the southeast of the country, where the climate and edaphic conditions are quite distinct from those found on the Amazon coast.

One other important consideration for the production of seedlings is the cost of production, which is considerable when compared with direct sowing. In conclusion, nurseries are only necessary when regeneration is unsuccessful by direct sowing, or when a certain degree of seedling development is necessary to guarantee recruitment [14]. As the maintenance of mangrove forests is dependent on seedling recruitment [15], the production of seedlings is essential in order to enhance the recruitment process and guarantee the viability of the new individuals, and thus accelerate the regeneration process for the ecosystem as a whole.

The region's growing human population has been the primary factor determining the ongoing degradation of the mangrove forests of the Brazilian Amazon region [10]. Given this, the present study investigated the viability of the production of seedlings of the three principal local mangrove species-Rhizophora mangle L., Avicennia germinans (L.) L., and Laguncularia racemosa (L.) C.F. Gaertn.-focusing in particular on the effects of different types of soil on the growth and survival of seedlings, and the potential of this procedure for the restoration of degraded mangrove forests on the Brazilian Amazon coast.

\section{Materials and Methods}

\subsection{Study Site}

The present study was developed in the village of Taperaçu-Campo $\left(00^{\circ} 56^{\prime} 55.07 " \mathrm{~S}, 46^{\circ} 46^{\prime} 00.82^{\prime \prime} \mathrm{W}\right)$, on the Ajuruteua Peninsula, $12 \mathrm{~km}$ north of the town of Bragança, in the northern Brazilian state of Pará (Figure 1). The region's climate is hot and humid, with a distinct dry season, from July to December, and a rainy season, between January and June, with mean annual precipitation of between $2500 \mathrm{~mm}$ and $3000 \mathrm{~mm}$, and mean temperatures of approximately $26^{\circ} \mathrm{C}$ [16]. The rivers are characterized by a semidiurnal macrotidal regime, with spring tide of over $5 \mathrm{~m}$ and neap tides of around $3 \mathrm{~m}$ in height [17] [18].

Four of the seven mangrove tree species found in the Neotropical region are present on the Ajuruteua Peninsula, although only three of these species—R. mangle, A. germinans, and L. racemosa-dominate the landscape, while Avicennia schaueriana Stapf and Leechman ex Moldenke is more sparsely distributed. It is important to note that the construction in the 1970s of the PA-458 state highway, which connects Bragança to the village of Ajuruteua, bisected $26 \mathrm{~km}$ of the local mangrove forest [10], and impacted an area of $3.8 \mathrm{~km}^{2}$ of this ecosystem [19]. These authors concluded that he primary source of this impact was the obstruction of the tidal creeks on the east of the peninsula, that drain into the Caeté River. 

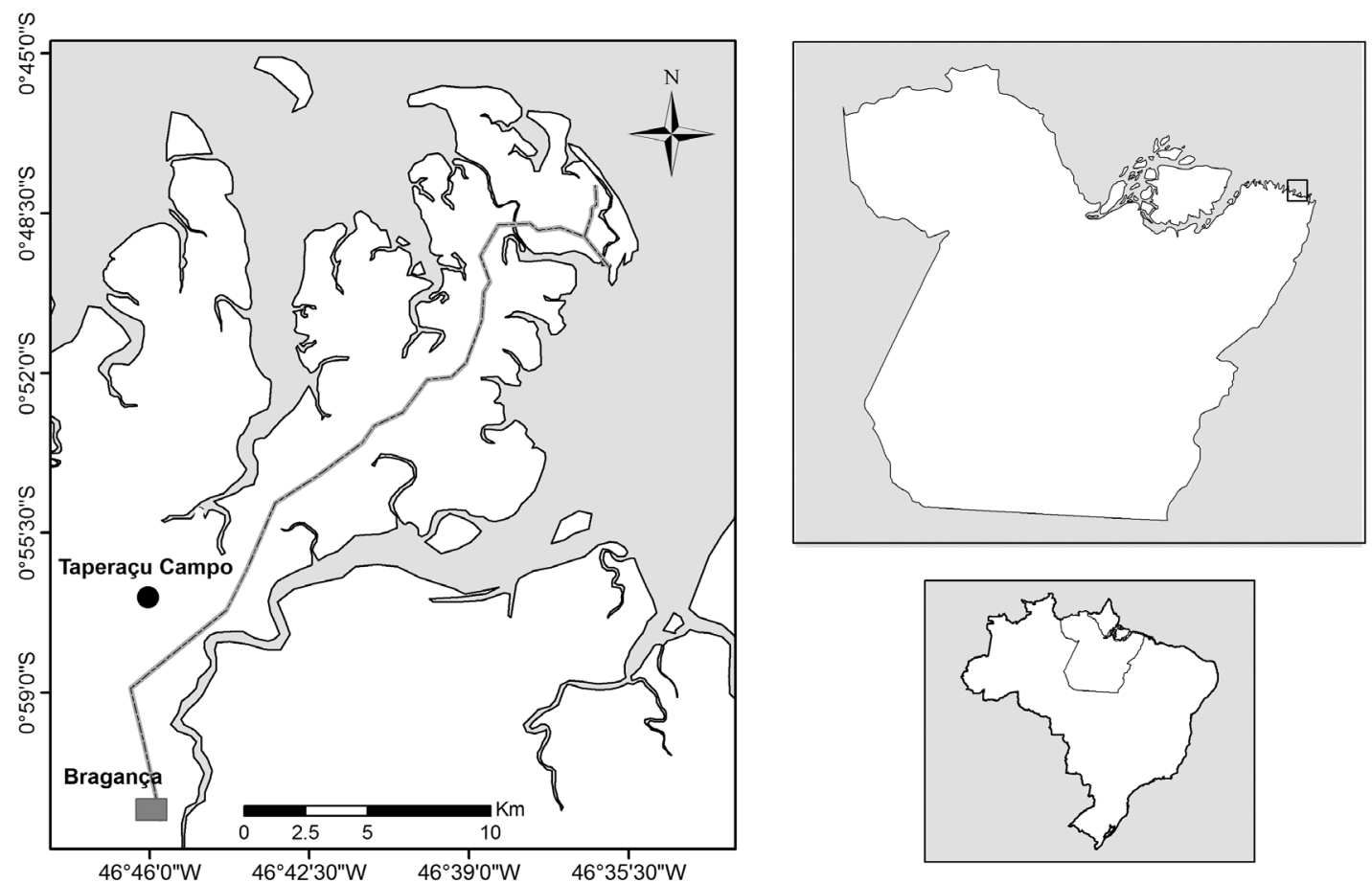

Figure 1. Map of the study area, showing the Taperaçu-Campo village on the Ajuruteua Peninsula in Bragança, Pará, Brazil.

\subsection{Seedling Production}

The nursery was established near a tidal creek, where a small ditch was dug to provide a water source, imitating a daily regime of inundation by tidal waters. The nursery occupied a total area of $32 \mathrm{~m}^{2}(8 \mathrm{~m} \times 4 \mathrm{~m}$, with a depth of $40 \mathrm{~cm}$ ), and was placed in the intertidal zone, where they have access to brackish water [20].

Peak fruiting in the mangrove tree species of the Amazon region corresponds to the rainy season [21]. Given this, the propagules of $R$. mangle, A. germinans, and L. racemosa were collected for the present study during the peak fruiting month of March. The propagules were either collected from the forest floor shortly after abscission or directly from the mother-tree, when known to be mature in $R$. mangle, the distal portion of the ripe propagule (hypocotyl) is brown in color [22], while those of A. germinans are green [15], the propagules of L. racemosa are brown in color when mature [23]. Mature propagules still attached to the tree can be identified easily because they fall readily when touched [24].

The A. germinans propagules were immersed in water for 24 hours in order to facilitate the removal of the tegument, while those of $L$. racemosa were immersed for approximately seven days, until the radicle emerged. The $R$. mangle propagules were not treated in any way.

The propagules were planted in $17 \mathrm{~cm} \times 27 \mathrm{~cm}$ polyethylene containers filled with one of three types of substrate-(i) mangrove soil, (ii) latosol, and (iii) sand. An average of four propagules were planted directly into the substrate of each container in order to compensate for losses, and guarantee the production of at least one seedling per container. Surplus seedlings were removed after 30 days, leaving only the best-developed seedling in each container.

\subsection{Experimental Design}

The seedlings selected for the three mangrove species were tested in relation to the effects of substrates on their survival and growth. The experimental design adopted for the present study was completely randomized, based on a $3 \times 3$ factorial ( 3 species $\times 3$ types of substrate). Each treatment included three replicates, each composed of 80 seedlings (total $=240$ ), and nine treatments were evaluated. Each of the different substrates tested in the present study were analyzed chemically in the EMBRAPA (Brazilian Agricultural Research Corporation for 
eastern Amazonia) soils laboratory in Belém, Brazil. For this, samples of $1 \mathrm{~kg}$ were obtained from a depth of 20 $\mathrm{cm}$ and stored in plastic bags labeled according to their origin.

Seedling survival rates were calculated based on the percentage of containers with seedlings 270 days after planting. For the assessment of growth, the height $(\mathrm{cm})$ of the seedlings was first measured 30 days after planting, and then every month over the nine months of the study period.

\subsection{Data Analyses}

The data were analyzed using standard statistical tests [25]. The effect of the different substrates on the survival and growth of the seedlings was evaluated using an Analysis of Variance (ANOVA), following the a priori testing of the data for normality (Lilliefors test for k samples) and homogeneity of variance (Cochran's test). The data are presented as means \pm standard deviations, while differences between treatments were considered significant at the $5 \%(p<0.05)$ level.

\section{Results and Discussion}

\subsection{Physical and Chemical Characteristics of the Substrate}

A good quality substrate, in both chemical and physical terms, is essential for the production of healthy seedlings of native forest species [26]. In the present study, the different substrates presented contrasting granulometric characteristics (Table 1), based on their textural fractions (sand, silt, and clay). This variation affected the survival rates and growth of the seedlings in the different substrates tested in the nursery.

In the mangrove soil, the survival rates recorded for A. germinans (98\%) and $R$. mangle (90\%) were higher than those observed for the sandy substrate (85\% for both species). These findings contrast with those of $\mathrm{Ab}$ rahão [27], who obtained a survival rate of only $37 \%$ for A. schaueriana seedlings grown in different types of substrate (compost + clay, compost + sand, and clay + sand), as well as clay and sand separately. This author nevertheless obtained much better results for $A$. schaueriana seedlings grown in nurseries-survival rates of up to $82 \%$ - using a mixture of sand and fertilizing compost (N, P, K).

With the exception of $\mathrm{Al}$ and $\mathrm{Zn}$, the highest values for the different nutrients analyzed were recorded in the mangrove soil (Table 1), reflecting its high fertility, which results from the high levels of $\mathrm{P}, \mathrm{K}, \mathrm{Ca}$, and $\mathrm{Mg}$, and reduced Al. A number of other studies have evaluated the affects of fertilization with N:P:K on the growth and accumulation of dry matter in mangrove tree species. In western Arabia, for example, authors demonstrated that the application of $\mathrm{K}$ resulted in a significant increase in the number of branches per plant in the later stage of development, while the addition of $\mathrm{N}$ had a similar effect on the dry weight of the leaves [28]. In another study, the production of seedlings in the nursery applied inorganic fertilizer (N:P:K-17:17:17, di-ammonia phosphate and urea) after 60 days in order to stimulate the growth and establishment of the roots [20]. In the present study, however, no fertilizer was applied, and seedling growth was dependent on the natural physical and chemical properties of the substrates tested.

\subsection{Seedling Survival}

In mangrove soil (Figure 2(a)), the survival rate recorded for A. germinans seedlings (95\%) was significantly higher than that those recorded for $R$. mangle and L. racemosa, which returned the lowest rate, at $60 \%$ (Table 2). High survival rates, of above $85 \%$, have been recorded in other studies of mangrove recuperation [29]. In a study of R. mangle in degraded mangroves on the coast of Chiapas, Mexico, for example, it was recorded a $100 \%$ survival rate after 120 days of growth in nurseries, with low mortality $(<5 \%)$ being recorded following transplantation [30].

In the sandy substrate (Figure 2(b)), the highest survival rates were recorded for R. mangle and A. germinans, while the lowest value (37\%) was recorded for $L$. racemosa, with a highly significant difference between the means values recorded for the former two species and that for L. racemosa (Table 2). These results are different from the results of Ellison \& Farnsworth [31], who found no significant difference in the survival rates of the three species.

In the latosol (Figure 2(c)), a survival rate of $75 \%$ was recorded for $R$. mangle, with much lower values being recorded for A. germinans (46\%) and L. racemosa (42\%). Trench \& Webber [32] compared the production of seedlings ( $R$. mangle, L. racemosa, A. germinans, and Conocarpus erectus L.) in a nursery with the natural 


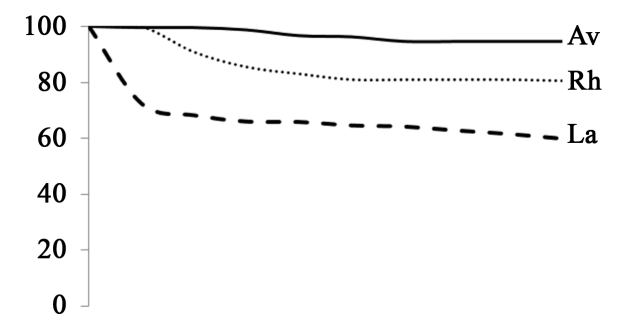

(a)

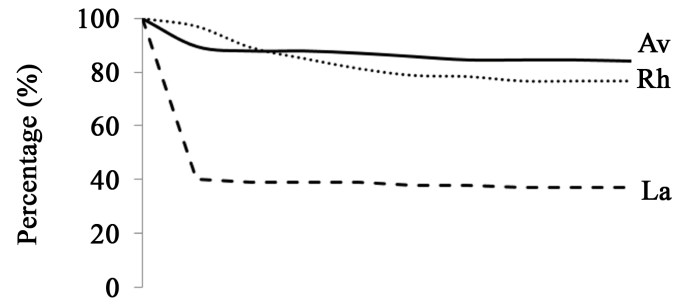

(b)

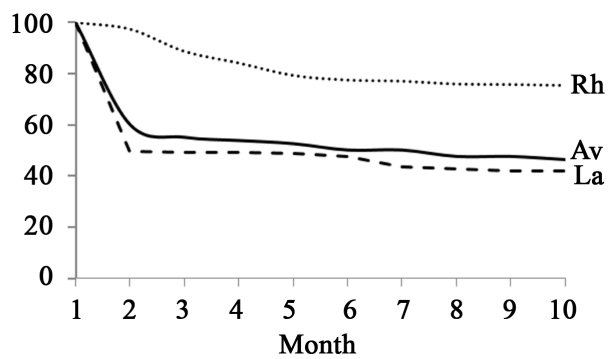

(c)

Figure 2. Survival rates of the seedlings of Rhizophora mangle (Rh), Avicennia germinans (Av), and Laguncularia racemosa (La) in mangrove soil (a); sand substrat (b) and latosol substrat (c) over a nine month period in the nursery at Taperaçu-Campo, Bragança, Pará, Brazil.

Table 1. Physical and chemical composition of the substrates used in the production of the seedlings of mangrove tree species. $\mathrm{pH}=$ Potential Hydrogen, $\mathrm{P}=$ Phosphorus, $\mathrm{K}=$ Potassium, $\mathrm{Na}=$ Sodium, $\mathrm{Ca}=$ Calcium, $\mathrm{Ca}+\mathrm{Mg}=\mathrm{Calcium}+\mathrm{Magne}-$ sium, $\mathrm{Al}=$ Aluminum, $\mathrm{Cu}=$ Copper, $\mathrm{Mn}=$ Manganese, $\mathrm{Fe}=$ Iron, and $\mathrm{Zn}=\mathrm{Zinc}$.

\begin{tabular}{cccc}
\hline Component & & Quantity found in: & Latosol \\
\cline { 2 - 4 } Coarse sand $(\mathrm{g} / \mathrm{kg})$ & Mangrove soil & Sand & 17 \\
Fine sand $(\mathrm{g} / \mathrm{kg})$ & 571 & 1 & 762 \\
Silt $(\mathrm{g} / \mathrm{kg})$ & 182 & 979 & 121 \\
Total Clay $(\mathrm{g} / \mathrm{kg})$ & 240 & 20 & 100 \\
$\mathrm{pH}$ & 6.0 & 4.7 & 5.0 \\
$\mathrm{P}\left(\mathrm{mg} / \mathrm{dm}^{3}\right)$ & 16.0 & 8.0 & 3.0 \\
$\mathrm{~K}\left(\mathrm{mg} / \mathrm{dm}^{3}\right)$ & 583 & 57 & 24 \\
$\mathrm{Na}\left(\mathrm{mg} / \mathrm{dm}^{3}\right)$ & 388 & 609 & 12 \\
$\mathrm{Ca}\left(\mathrm{cmol} / \mathrm{dm}^{3}\right)$ & 1.9 & 0.9 & 0.4 \\
$\mathrm{Ca}+\mathrm{Mg}\left(\mathrm{cmol} / \mathrm{dm}^{3}\right)$ & 8.2 & 1.6 & 0.7 \\
$\mathrm{Al}\left(\mathrm{cmol} / \mathrm{dm}^{3}\right)$ & 0.1 & 0.1 & 1.4 \\
$\mathrm{Cu}(\mathrm{mg} / \mathrm{kg})$ & 7.1 & 4.3 & 5.2 \\
$\mathrm{Mn}(\mathrm{mg} / \mathrm{kg})$ & 14.8 & 12.8 & 14.6 \\
$\mathrm{Fe}(\mathrm{mg} / \mathrm{kg})$ & 136.0 & 555.0 & 135.6 \\
\hline
\end{tabular}

Extractor method. EMBRAPA-Belém. 
Table 2. Results of the ANOVA for the survival (\%) of the seedlings of the mangrove tree species $(\mathrm{Rh}=$ Rhizophora mangle, $\mathrm{Av}=$ Avicennia germinans, and $\mathrm{La}=$ Laguncularia racemosa $)$ in the three types of substrate tested over the nine months of the study period. Values are the means \pm standard deviation for each species. $\mathrm{MS}=$ mean square, $\mathrm{F}=\mathrm{F}$ value $(\mathrm{ANOVA}), p=$ significance at the $5 \%$ level.

\begin{tabular}{ccccc}
\hline Source of variation & $(\mathrm{Rh} \pm \mathrm{SD}) \times(\mathrm{Av} \pm \mathrm{SD}) \times(\mathrm{La} \pm \mathrm{SD})$ & $\mathrm{MS}$ & $\mathrm{F}$ & $p$ \\
\hline spp. $\times$ mangrove soil & $(69.1 \pm 05.99) \times(77.7 \pm 01.77) \times(54.9 \pm 08.76)$ & 0.13 & 30.75 & 0.001 \\
spp. $\times$ sand & $(67.1 \pm 06.61) \times(70.2 \pm 03.58) \times(35.5 \pm 14.86)$ & 0.36 & 35.79 & 0.001 \\
spp. $\times$ latosol & $(66.6 \pm 06.96) \times(44.4 \pm 12.08) \times(41.2 \pm 13.14)$ & 0.19 & 13.73 & 0.01 \\
\hline
\end{tabular}

rates observed in plots established within the forest. While a marked difference was recorded for $R$. mangle—93\% in the nursery versus only $10 \%$ in the forest-similar survival rates were recorded for C. erectus and A. germinans in the two environments.

The survival of mangrove trees depends on a range of environmental factors. In a mangrove forest in Espírito Santo, Brazil, for example, mortality rates in $R$. mangle seedlings were determined by a combination of environmental factors and inter-individual competition, whereas in $L$. racemosa was affected only by competition. In this case, while the population density of $L$. racemosa was lower, this species appeared to be better adapted to the local abiotic conditions [33].

A number of biological processes may also affect the survival strategies of seedlings in mangrove forests, however. Unlike R. mangle and A. germinans, for example, L. racemosa is not viviparous, and germination often occurs during the dispersal process [15]. Viviparity may increase the chances of the propagules surviving in relatively saline, sludgy environments, with low levels of oxygen, in which the germination of seeds would normally be inhibited. While the present study was conducted in a nursery, the lowest survival rates were recorded for L. racemosa, indicating a germination pattern similar to that recorded in the natural environment.

It is important to note that the production of seedlings for the recuperation of degraded mangroves may result in increased survival and better development of the plants than those already present in the natural environment. Similar results were obtained in a more arid region [34]. These findings indicate that the establishment of a nursery for the production of mangrove seedlings within the natural environment is an essential complementary strategy for the recuperation of these habitats, especially where the natural regeneration process in relatively slow and discontinuous.

\subsection{Seedling Growth}

The results of the ANOVA for seeding growth (Table 3 ) indicated that there was no significant difference in growth (height) among the seedlings of $R$. mangle, A. germinans or L. racemosa analyzed from the mangrove substrate (ANOVA: $\mathrm{F}=0.17$, d.f. $=2, p>0.05$, Figure 3(a)). Similarly, no significant difference was recorded for the sandy substrate $(\mathrm{F}=0.15$, d.f. $=2, p>0.05$, Figure $3(\mathrm{~b}))$ or latosol $(\mathrm{F}=0.11$, d.f. $=2, p>0.05$, Figure $3(\mathrm{c}))$. These findings contradict those reported by Castanheira and Carrasco [11], who recorded the highest growth rates in seedlings grown in a peat-sand mix.

Overall, then, the results of the present study indicated that an adequate chemical and physical composition of the substrate is essential for the rapid growth and development of the seedling of mangrove tree species ( $R$. mangle, A. germinans, and L. racemosa). It is important to remember, however, that the propagules of these species are able to develop independently of the substrate tested. In fact, the propagules of these species retain sufficient reserves of nutrients in order to guarantee the establishment of their cotelydons, even after nine months. During the initial growth period, the cotelydons are fundamentally important for the absorption of resources prior to germination, and even after this process, when they emerge from the tegument of the seed to initiate photosynthesis [35]. Clearly, then, the mangrove species analyzed in the present study are highly productive under nursery conditions [36], which is highly advantageous for the recuperation and restoration of degraded mangrove habitats.

\section{Conclusion}

The results of the present study indicate that the seedlings of R. mangle and A. germinans survived at higher 


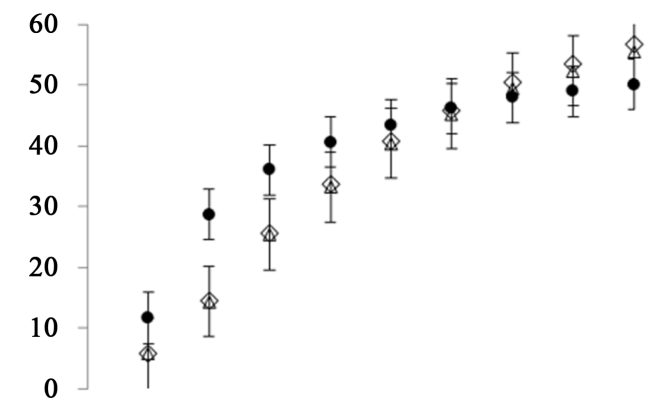

(a)

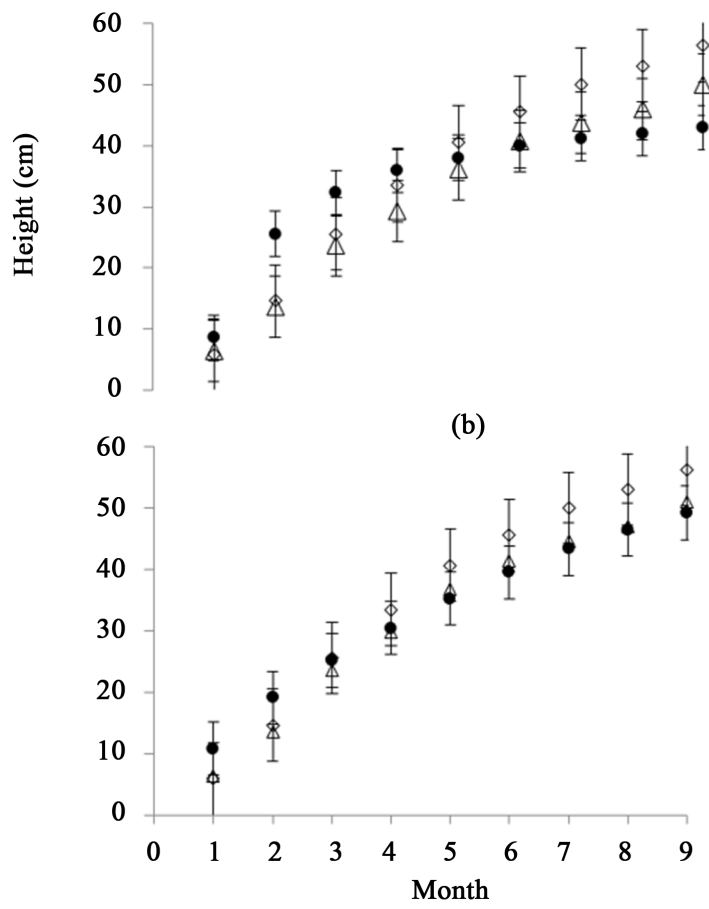

$\diamond \mathrm{Rh}$

- Av

$\triangle \mathrm{La}$

(c)

Figure 3. Growth of the seedlings of Rhizophora mangle (Rh), Avicennia germinans (Av), and Laguncularia racemosa (La) in mangrove soil (a); sand substrat (b) and latosol substrat (c) over a nine month period in the nursery at Taperaçu-Campo, Bragança, Pará, Brazil.

Table 3. Results of the ANOVA for the growth $(\mathrm{cm})$ of the seedlings of the mangrove tree species $(\mathrm{Rh}=$ Rhizophora mangle, $\mathrm{Av}=$ Avicennia germinans, and La $=$ Laguncularia racemosa $)$ in the three types of substrate tested over the nine month period. Values are the means \pm standard deviation for each species. $\mathrm{MS}=$ mean square, $\mathrm{F}=\mathrm{F}$ value (ANOVA), $p=$ significance at the $5 \%$ level.

\begin{tabular}{ccccc}
\hline Source of variation & $(\mathrm{Rh} \pm \mathrm{SD}) \times(\mathrm{Av} \pm \mathrm{SD}) \times(\mathrm{La} \pm \mathrm{SD})$ & $\mathrm{MS}$ & $\mathrm{F}$ & $p$ \\
\hline spp. $\times$ mangrove soil & $(36.32 \pm 16.85) \times(39.35 \pm 11.74) \times(35.82 \pm 16.45)$ & 41.23 & 0.17 & 0.83 \\
spp. $\times$ sand & $(36.10 \pm 16.67) \times(34.04 \pm 10.33) \times(32.82 \pm 16.45)$ & 34.89 & 0.15 & 0.85 \\
spp. $\times$ latosol & $(36.06 \pm 16.63) \times(32.29 \pm 12.24) \times(32.62 \pm 14.62)$ & 27.37 & 0.11 & 0.89 \\
\hline
\end{tabular}

rates on the substrates tested in the nursery than L. racemosa. However, all three species grew well in the substrates tested, and the production of seedlings in yellow latosol would appear to be the most effective approach, considering the availability of this material on the Amazon coast and its ease of use, as well as the potential avoidance of further intervention into the mangrove ecosystem. 


\section{References}

[1] Spalding, M., Blasco, F. and Field, C. (2010) World Mangrove Atlas. The International Society for Mangrove Ecosystems, Okinawa.

[2] Souza Filho, P.W. (2005) Costa de manguezais de macromaré da Amazônia: Cenários morfológicos, mapeamento e quantificação de áreas usando dados de sensores remotos. Revista Brasileira de Geofísica, 23, 427-435. http://dx.doi.org/10.1590/S0102-261X2005000400006

[3] Mitsch, W.J. and Gosselink, J.G. (2000) Wetlands. John Wiley \& Sons, New York.

[4] Benfield, S.L., Guzman, H.M. and Mair, J.M. (2005) Temporal Mangrove Dynamics in Relation to Coastal Development in Pacific Panama. Journal of Environmental Management, 76, 263-276. http://dx.doi.org/10.1016/j.jenvman.2005.02.004

[5] Dahdouh-Guebas, F., Hettiarachchi, S., Lo Seen, D., Batelaan, O., Sooriyarachchi, S., Jayatissa, L.P. and Koeda, N. (2005) Transitions in Ancient Inland Freshwater Resource Management in Sri Lanka Affect Biota and Human Populations in and around Coastal Lagoons. Current Biology, 15, 579-586. http://dx.doi.org/10.1016/j.cub.2005.01.053

[6] Jupiter, S.D., Potts, D.C., Phinn, S.R. and Duke, N.C. (2007) Natural and Anthropogenic Changes to Mangrove Distributions in the Pioneer River Estuary (QLD, Australia). Wetland Ecology and Management, 15, 51-62. http://dx.doi.org/10.1007/s11273-006-9011-9

[7] Thu, P.M. and Populus, J. (2007) Status and Changes of Mangrove Forest in Mekong Delta: Case Study in Tra Vinh, Vietnam. Estuarine Coastal and Shelf Science, 71, 98-109. http://dx.doi.org/10.1016/j.ecss.2006.08.007

[8] Guimarães, A.S., Travassos, P. and Souza Filho, P.W. (2010) Impact of Aquaculture on Mangrove Areas in the Northern Pernambuco Coast (Brazil) Using Remote Sensing and Geographic Information System. Aquaculture Research, 41, 828-838. http://dx.doi.org/10.1111/j.1365-2109.2009.02360.x

[9] Suhogusoff, V.G. and Piliackas, J.M. (2007) Breve histórico da ação antrópica sobre os ecossistemas costeiros do Brasil, com ênfase nos manguezais do estado de São Paulo. Integração, 51, 343-351.

[10] Fernandes, M.E.B., Fernandes, J.S., Muriel-Cunha, J., Sedovim, W.R., Gomes, I.A., Santana, D.S., Sampaio, D.S., Andrade, F.A.G., Oliveira, F.P., Brabo, L.B., Silva-Junior, M.G. and Elias, M.P. (2007) Efeito da construção da rodovia PA-458 sobre as florestas de mangue da Península bragantina, Bragança, Pará, Brasil. Uakari, 3, 55-63.

[11] Castanheira, A.S. and Carrasco, G.P. (2004) Teste de substrato para produção de Rhizophora mangle sob condições de viveiro florestal. Arquivo do Instituto Biológico, 71, 188-337.

[12] Zamith, L.R. and Scarano, F.R. (2004) Produção de mudas de espécies das Restingas do município do Rio de Janeiro, RJ, Brasil. Acta Botanica Brasilica, 18, 161-176. http://dx.doi.org/10.1590/S0102-33062004000100014

[13] Cunha, A.M., Cunha, G.M., Sarmento, R.A. and Amaral, J.F.T. (2006) Efeito de diferentes substratos sobre o desenvolvimento de mudas de Acacia sp. Revista Árvore, 30, 207-214. http://dx.doi.org/10.1590/S0100-67622006000200007

[14] Saenger, P. (1997) Restauración de manglares em Australia. Estúdio de caso del aerupuerto internacional de Brisbane. In: Field, C., Ed., La Restauración de Ecosistemas del Manglar, International Society for Mangrove Ecosystems, Okinawa, 37-55.

[15] Tomlinson, P.B. (1994) The Botany of Mangroves. Cambridge University Press, Cambridge.

[16] Moraes, B.C., Costa J.M.N. and Costa, A.C.L. (2005) Variação espacial and temporal da precipitação no estado do Pará. Acta Amazonica, 35, 207-214. http://dx.doi.org/10.1590/S0044-59672005000200010

[17] Koch, V. and Wolff, M. (2002) Energy Budget and Ecological Role of Mangrove Epibenthos in the Caeté Estuary, North Brazil. Marine Ecology Progress Series, 228, 119-130. http://dx.doi.org/10.3354/meps228119

[18] Marques-Silva, N.S., Beasley, C.R., Paiva, G.C., Lima G.D.C., Tagliaro C.H., Schories, D. and Mehlig, U. (2006) Settlement Dynamics of the Encrusting Epibenthic Macrofauna in Two Creeks of the Caeté Mangrove Estuary (North Brazil). Wetlands Ecology and Management, 14, 67-78. http://dx.doi.org/10.1007/s11273-005-2568-x

[19] Lara, R.J. and Cohen, M.C.L. (2003) Sensoriamento Remoto. In: Fernandes, M.E.B., Ed., Os manguezais da costa norte brasileira, Fundação Rio Bacanga, São Luís, 11-28.

[20] Ravishankar, T. and Ramasubramanian, R. (2004) Manual on Mangrove Nursery Techniques. M.S. Swaminathan Research Foundation, Chennai.

[21] Fernandes, M.E.B., Virgulino, A.R.C., Nascimento, A.A.M. and Rodrigues L.F.P. (2005) Padrões de floração and frutificação em Laguncularia racemosa (L.) Gaertn. F.: uma avaliação metodológica. Boletim do Laboratório de Hidrobiologia, 18, 33-38.

[22] Duke, N.C. and Allen, J.A. (2006) Rhizophora mangle, R. samoensis, R. racemosa, R. × harrisonii (Atlantic-East Pacific Red Mangrove). Species Profiles for Pacific Island Agroforestry, 10, 1-18. 
[23] Rabinowitz, D. (1978) Dispersal Properties of Mangrove Propagules. Biotropica, 10, 47-57. http://dx.doi.org/10.2307/2388105

[24] Cavalcanti, V.F., Andrade, A.C.S. and Soares, M.L.G. (2007) Germination of Avicennia schaueriana and Laguncularia racemosa from Two Physiographic Types of Mangrove Forest. Aquatic Botany, 86, 285-290. http://dx.doi.org/10.1016/j.aquabot.2006.10.008

[25] Ayres, M., Ayres, M.J., Ayres, D.L. and Santos, A.A. (2007) BioEstat 5.0: Aplicacões estatísticas nas áreas das ciências biológicas and médicas. Sociedade Civil Mamirauá/CNPq, Belém.

[26] Gonçalves, J.L.M., Santarelli, E.G. and Moraes Neto, S.P. (2000) Produção de mudas de espécies nativas: substrato, nutrição, sombreamento and fertilização. In: Gonçalves, J.L.M. and Benedetti, V., Eds., Nutrição e fertilização florestal, IPEF, Piracicaba, 309-350.

[27] Abrahão, R.G. (1998) Uma nova concepção paisagística em obras de engenharia em regiões litorâneas com plantas nativas de manguezal (Via Expressa Sul-Ilha de Santa Catarina-Brasil). MSc Dissertation, Universidade Federal de Santa Catarina, Florianópolis.

[28] AboHassan, A.A. and Osman, H.E. (2002) Effect of NPK Fertilization on Growth and Dry Matter Accumulation in Mangrove (Avicennia marina (Forsk) Vierh) Grown in Western Saudi Arabia. JKAU: Meteorology Environment and Arid Land Agriculture Science, 21, 57-70.

[29] Padrón, C.M. (1997) Restauración de ecosistemas de manglar em Cuba: estudio de caso de Provincia Habana. In: Field, C., Ed., La restauración de ecosistemas del manglar, International Society for Mangrove Ecosystems, Okinawa, 176186.

[30] Reyes, M.A. and Tovilla, C.H. (2002) Restauración de áreas alteradas de manglar con Rhizophora mangle en la Costa de Chiapas. Madera y Bosques, 8, 103-114.

[31] Ellison, A.M. and Farnsworth, E.J. (1993) Seedlings Survival, Growth and Response to Disturbance in Belize Mangal. American Journal of Botany, 80, 1137-1145. http://dx.doi.org/10.2307/2445541

[32] Trench, C.A. and Webber, M.K. (2011) Nursery Propagation of Jamaican Coastal Forest Species. Acta Horticulturae (ISHS), 894, 185-190. http://dx.doi.org/10.17660/ActaHortic.2011.894.20

[33] Tognella, M.M.P., Lima, K.O.O., Oliveira, R.C. and Coelho, N.F. (2011) Mortalidade de plântulas de Rhizophora mangle L. and Laguncularia racemosa (L.) Gaertn. f. em um bosque de bacia no manguezal do rio Itaunas, ES, Brasil. $\mathrm{X}$ Congresso de Ecologia do Brasil, São Lourenço.

[34] Toledo, G., Rojas, A. and Bashan, Y. (2001) Monitoring of Black Mangrove Restoration with Nursery-Reared Seedlings on an Arid Coastal Lagoon. Hydrobiologia, 444, 101-109. http://dx.doi.org/10.1023/A:1017552305401

[35] Marshall, P.E. and Kozlowiski, T.T. (1976) Importance of Photosynthetic Cotyledons for Early Growth of Woody Angiosperms. Physiology Plant, 37, 336-340. http://dx.doi.org/10.1111/j.1399-3054.1976.tb03981.x

[36] Field, C.D. (1998) Rehabilitation of Mangrove Ecosystems: An Overview. Marine Pollution Bulletin, 37, $383-392$. http://dx.doi.org/10.1016/S0025-326X(99)00106-X

\section{Submit or recommend next manuscript to OALib Journal and we will provide best service for you:}

- Publication frequency: Monthly

- 9 subject areas of science, technology and medicine

- Fair and rigorous peer-review system

- Fast publication process

- Article promotion in various social networking sites (LinkedIn, Facebook, Twitter, etc.)

- Maximum dissemination of your research work

Submit Your Paper Online: Click Here to Submit

Contact Us: service@oalib.com 